\title{
Remote Sensing Role in Applied Science and Technology
}

\author{
Togi Tampubolon ${ }^{1}$, Juniar Hutahean ${ }^{2}$, Rahmatsyah ${ }^{3}$ \\ \{topartam@gmail.com \} \\ Department of Physics, State University of Medan, Indonesia
}

\begin{abstract}
This study was conducted : -To prove whether remote sensing can be accepted in science and technology, -see the changes in the environment and critical land. To get the information of an object, the principle of reflection in physics was used. Sunlight comes to the earth surface and an object or wave is brought to the object, then the object reflects back the wave spectrum corresponding to the object characteristics into space and captured by the sensor as a data source that will be processed using a computer. Thus, the reflected object characteristics will be known. The results of the study: -prove that remote sensing can be used to observe the desired earth surface, -and there is environmental changes by looking at the greenness index (NDVI) and surface temperature (LST) and, -there is land curvature. This study also recommends that: Remote sensing can be used to monitor the earth surface widely.
\end{abstract}

Keywords: Remote Sensing, environmental change, critical land

\section{Introduction}

The surface of our earth has an area about 510,072,000 km2, and Indonesia has $6981369 \mathrm{~km} 2$. To observe environmental changes condition on the earth surface and our so vast country, it requires expensive energy, thought, time, and cost. This is a separate challenge / problem for science and technology. Nowadays, the development of science and technology that can answer those problems is namely remote sensing technology. Remote Sensing is the science and art of obtaining information about an object, area or phenomenon through analysis of data obtained with a device without direct contact with objects, regions or phenomena that are studied. [1] Remote Sensing is a variety of techniques developed for obtaining and analyzing information about the earth. Is Remote Sensing able to monitor and identify of the earth surface.

Monitoring (PL) can be done by utilizing remote sensing technology. Remote Sensing Technology has the ability to monitor a wide area, a relatively long period of time, with a fast and low cost period. Some studies that previously used remote sensing: Vegetation and surface temperature relations [2], effectively monitor the environment and analyze patterns in urban areas [3], critical land [4] [5], critical land monitoring [6], and vegetation relations critical land [7]. Monitoring of environmental damage with Remote Sensing Technology in Indonesia, especially in North Sumatra has not been carried out until 2016. Monitoring environmental damage by analyzing comprehensively variables such as: Green surface level of the Earth (NDVI), Earth surface temperature (LST), Land Use \& Land Cover, Forest Mangroves, soil surface inertia, soil pH, and Critical Land are carried out.

Science is something that is known to man through his life experience and will become knowledge if it has Been Proven True While Technology Is An Invention Through A Scientific Process To Achieve Its Goals In A More Simple Way. Does Remote Sensing Technology Play A Role In Applied Science? This Study Conducted Experiments And Field Surveys Using Cropsan Spectrometers, Thermometers, GPS, Satellite Data And Others To Test Whether The Intensity Of Light Coming To The Earth Surface Would Be The Same With That Reflected And Captured By Sensors On Landsat Satellites, Whether The Results Of Temperature Measurements In The Field Manually Same As The Calculation Results From Satellite Data. Furthermore, The Results Of The NDVI And LST Research Will Be Presented And Discussed As Well As The Relationship Between The Two In The Form Of Indexes And Maps To See Environmental Changes And Land Damage Which Ends With The Presentation Of The Critical Land Research Results. 


\section{Research Methodology}

\subsection{Data Analysis}

1. Collecting references and literature material about the remote sensing benefits

2. Using crops an spectrometer

3. Calculating NDVI with the equation.

4. Calculating the NDVI value by using the Transform function tools, NDVI with the formula: $N D V I=\frac{N I R-R E D}{N I R+R E D}$

5. Performing LST calculations with equation:

Where:

$$
T I=\left(\frac{K_{2}}{\ln \left(\frac{K_{1}}{L_{\lambda}}+1\right)}\right)
$$

$\mathrm{K}_{1}=$ Constanta 1 (774.89)

$\mathrm{K}_{2}=$ Constanta 2 ( 1321.08)

6. Performing index calculations

$$
\begin{aligned}
& \text { a. } \text { Humidity } \quad \text { TVDI }=\frac{T-T S m i n}{a+b N D V I-T S m i n} \\
& \text { b. } \text { Mangrove } I M=\left(N I R-\frac{S W I R}{N I R} * S W I R\right) * 10000 \\
& \text { c. } \text { Critical Land }
\end{aligned}
$$

7. For getting the value of critical land, 4 quantities below must be known. They are:

a. Vegetation Density $F C D=(V D+A S I+1) * 0.5-1$

b. Slope $L S=\left(X * \frac{C Z}{22.13}\right) *\left(\frac{\sin \vartheta}{0.0896}\right)$

Critical Land Index Calculation : $I L K=\{(a x C)+(b x S)+(c x E)+(d x M)\}$

\section{Result And Discussion}

\subsection{Spectroradiometer Survey Result}

Reflectance of electromagnetic waves can be detected by spectrometer and satellite remote sensing. Spectrometer Cropscan MSR 16R can be detected electromagnetic wave $520 \mathrm{~nm}$ until $2700 \mathrm{~nm}$, and Landsat sattelite image can be detected electromagnetic wave $450 \mathrm{~nm}$ until $2350 \mathrm{~nm}$. Sample field measurement results for each of land cover type could be seen in table 3.1 .

Table 1. Relationship of spectral reflectance value measurement using spectrometer Cropscan MSR 16R and Landsat 5 TM for each land cover type

\begin{tabular}{lllc}
\hline $\begin{array}{l}\text { Land } \\
\text { type }\end{array}$ & $\begin{array}{l}\text { cover } \\
\text { (Spearman Model) }\end{array}$ & Linear equation & $\begin{array}{c}\text { Determination } \\
\text { value } \mathrm{R}^{2}(\%)\end{array}$ \\
\hline A11 & 0.98 & $\mathrm{y}=0,81 \mathrm{x}+3.57$ & $97 \%$ \\
$\mathrm{~A} 12$ & 0.98 & $\mathrm{y}=0,67 \mathrm{x}+4.42$ & $96 \%$ \\
$\mathrm{~A} 21$ & 0.97 & $\mathrm{y}=0,77 \mathrm{x}+2.68$ & $94 \%$ \\
$\mathrm{~B} 11$ & 0.98 & $\mathrm{y}=0,93 \mathrm{x}+5.55$ & $97 \%$ \\
$\mathrm{~B} 12$ & 0.92 & $\mathrm{y}=0,81 \mathrm{x}+6.88$ & $96 \%$ \\
B21 & 0.61 & $\mathrm{y}=1,40 \mathrm{x}+5.53$ & $37 \%$ \\
B22 & 0.95 & $\mathrm{y}=0,43 \mathrm{x}+4,66$ & $91 \%$ \\
\hline
\end{tabular}


Where the result was a high correlation indicated that the classification results together with the results of field surveys Landsat, meant to further results from the Landsat satellite trustworthy used for classification, for the next satellite data can be used. [8]

\subsection{Temperature Measurement Results}
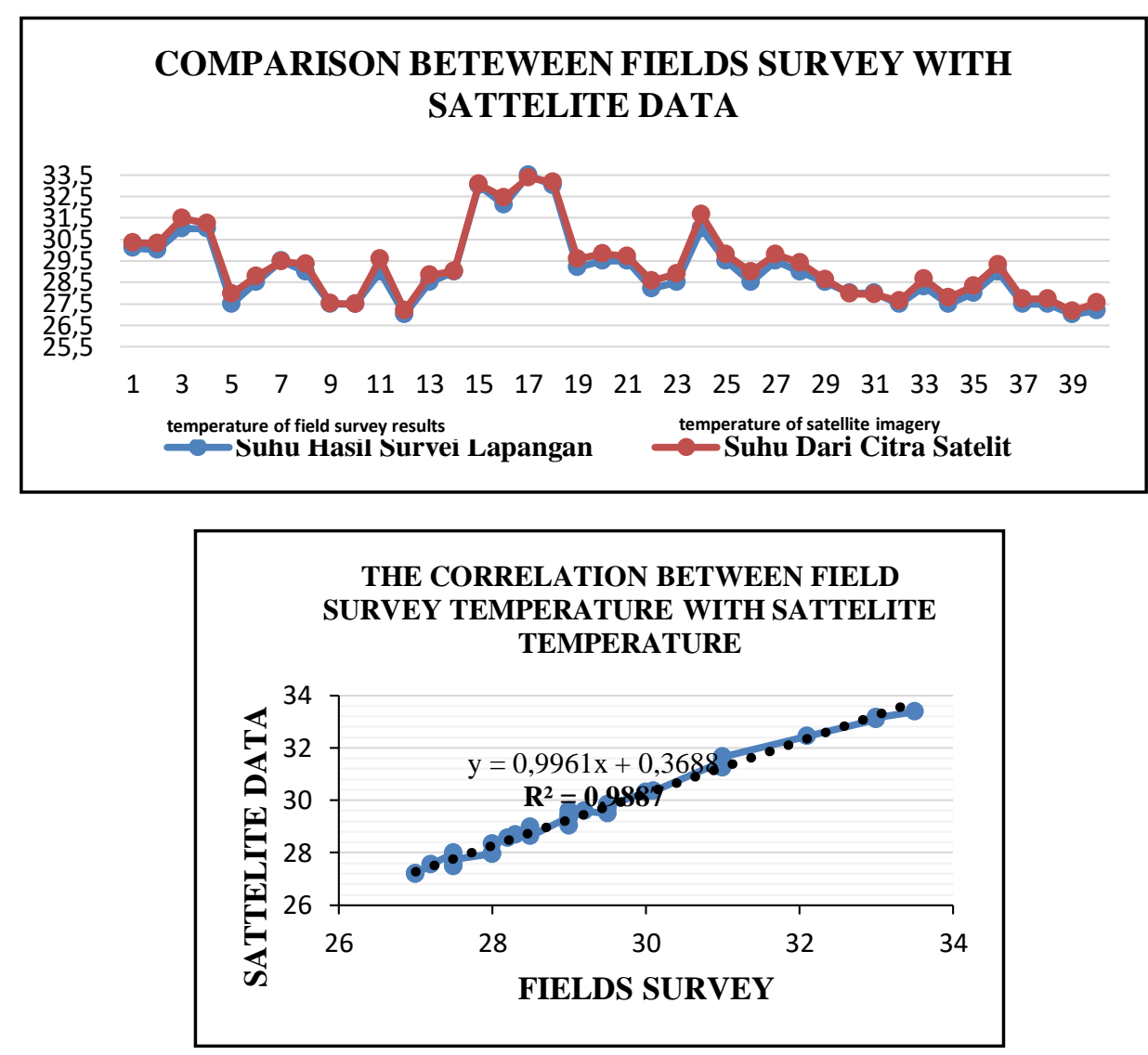

Figure 1. Comparison between the temperatures obtained from field surveys and temperature obtained from satellite data and their correlation. [9]

\subsection{Ndvi}

Map of NDVI calculation results in Sinabung Mountain area from 2011 to 2017 can be seen in Figure1.a, 1.b, and 1.c below

Figure 2.a NDVI Landsat 8 Oli in 2011

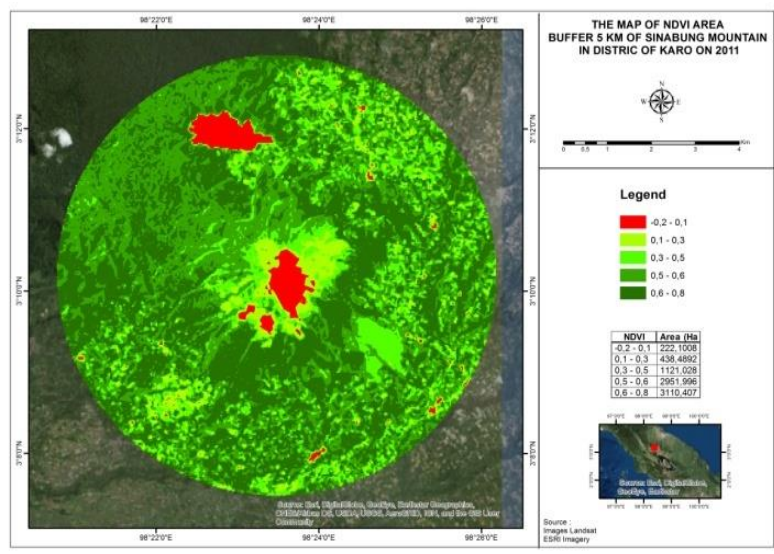

Figure 2.b NDVI Landsat 8 Oli in 2015

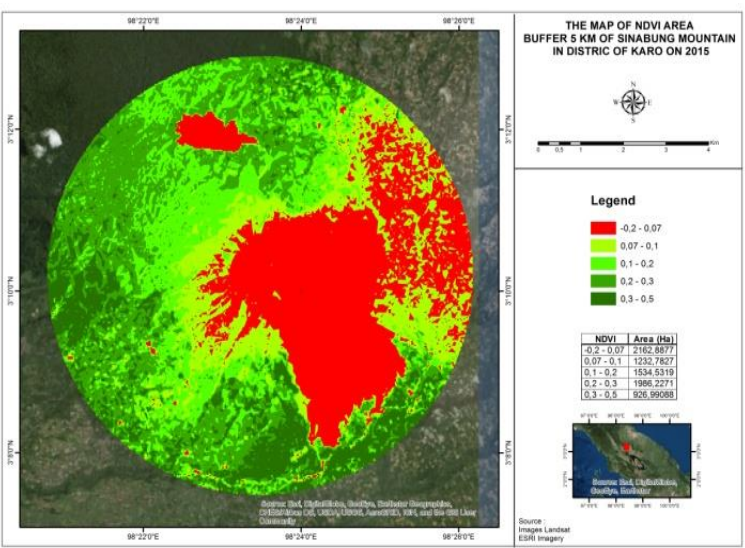




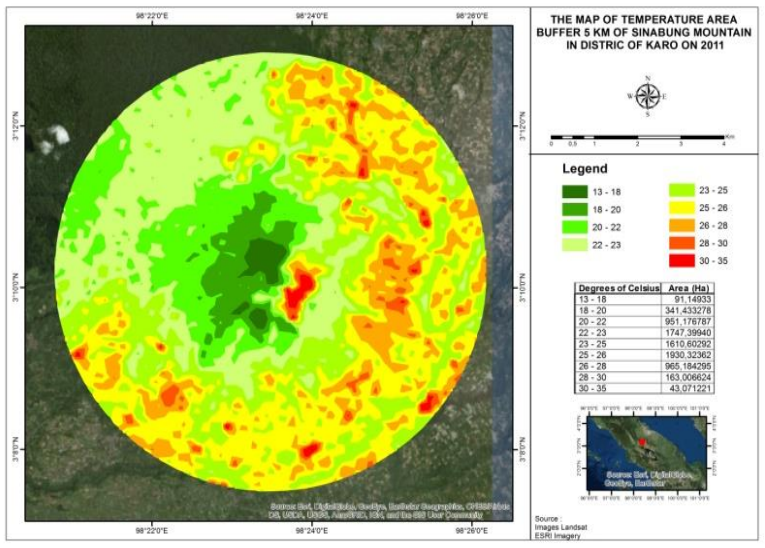

Figure 2.c NDVI Landsat 8 Oli in 2017

From the figure above, It can be seen that NDVI calculation results in 2011, 2015, 2017 in the Sinabung mountain area that each year the vegetation density had a significant decrease which we can see in table 1 below:

Table 2. The NDVI value has decreased every year

\begin{tabular}{ccc}
\hline No & Year & NDVI Value \\
\hline 1 & 2011 & $0.6-0.8 \mathrm{emu}$ \\
2 & 2015 & $0.4-0.5 \mathrm{emu}$ \\
3 & 2017 & $0.3-0.4 \mathrm{emu}$ \\
\hline
\end{tabular}

\subsection{Lst}

For temperature index contour maps in Sinabung Mountain area from 2011-2017, it can be seen in Figure 2.a, 2.b and 2.c below. The picture above shows that the LST value has decreased so dramatically and it is very clear that the increase is quite drastic, from the temperature data from 2011, 2015 and 2017 that have been obtained; the average temperature change that occurs in Sinabung Mountain area can be concluded. The highest temperature value is quite dramatic as in Table 2 below

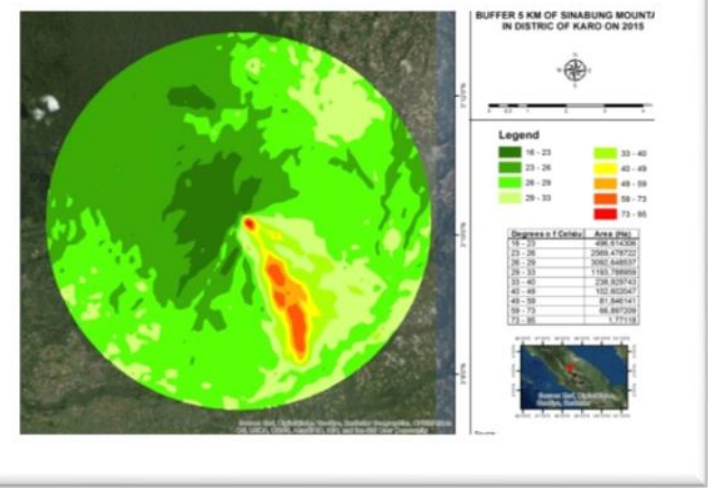

Figure 3.a LST Landsat 8 Oli in 2011

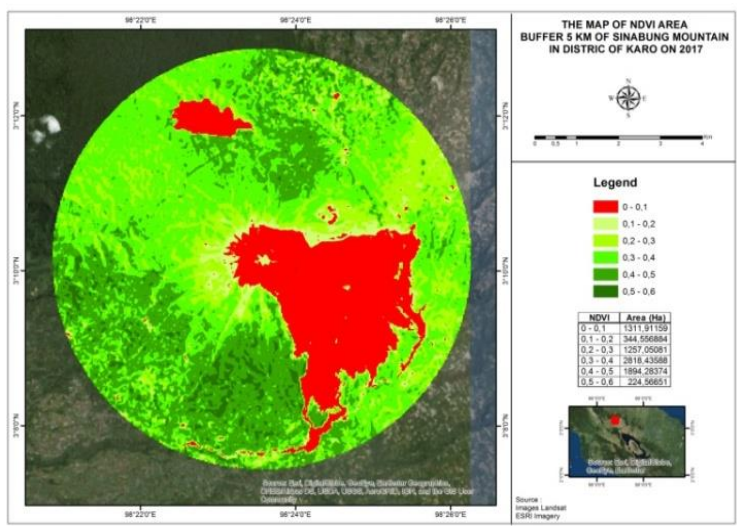

Figure 3.b LST Landsat 8 Oli in 2015 


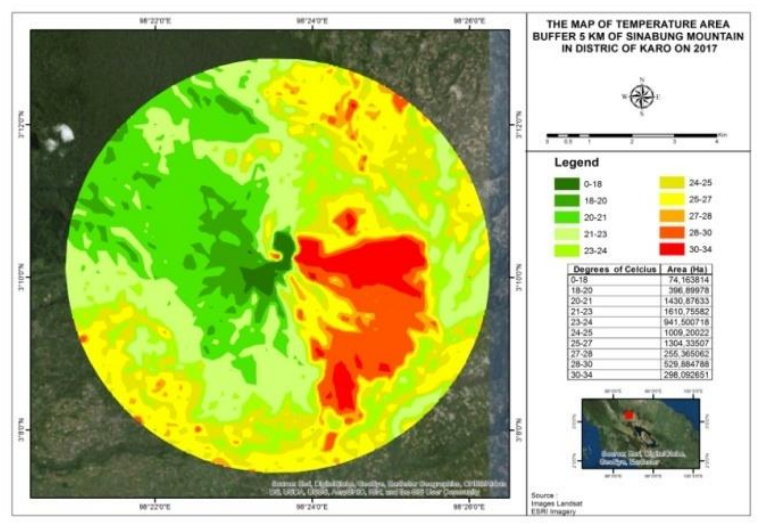

Figure 3.c LST Landsat 8 Oli in 2017

Table 3. The highest temperature value Table

\begin{tabular}{rll}
\hline No & Year & LST Value \\
\hline 1 & 2011 & $30-45{ }^{0} \mathrm{C}$ \\
2 & 2015 & $73-95{ }^{0} \mathrm{C}$ \\
3 & 2017 & $30-34{ }^{0} \mathrm{C}$ \\
\hline
\end{tabular}

\subsection{Land Damage}

Before Sinabung Mountain had eruption, the surrounding top area of Sinabung was still relatively green so there was no land damage because according to information obtained that Sinabung Mountain was a favorite tourist attraction for tourists who like climbing. However, since the activities of Mount Sinabung were reactivated in 2010, there are now a lot of eruption impacts of the mountain. One of them is land damage caused by lava flows and volcanic ash bursts. From the calculation of NDVI and LST on Landsat 8 imagery OLI in 2015 and 2017, it provides an overview of the area and area spread which suffered damage in the $5 \mathrm{~km}$ buferring due to the activities of.

From the land damage map above, it was concluded that there had been land damage resulting from the Sinabung Mountain eruption. It was seen in 2015, it was very significant because the effect after the Sinabung Mountain eruption in 2013 was affecting, the effect was very large regarding the land damage around the mountain.

To see land damage change in every year, it can be seen in table 3 below. From the table it can be stated that a decrease in NDVI values proves that land damage can be calculated.

From the table above it can be stated that the area with the most damage in 2015 was due to the high temperature on the surface that was damaged.

Figure 3.c Land Damage Landsat 8 Oli in 2015

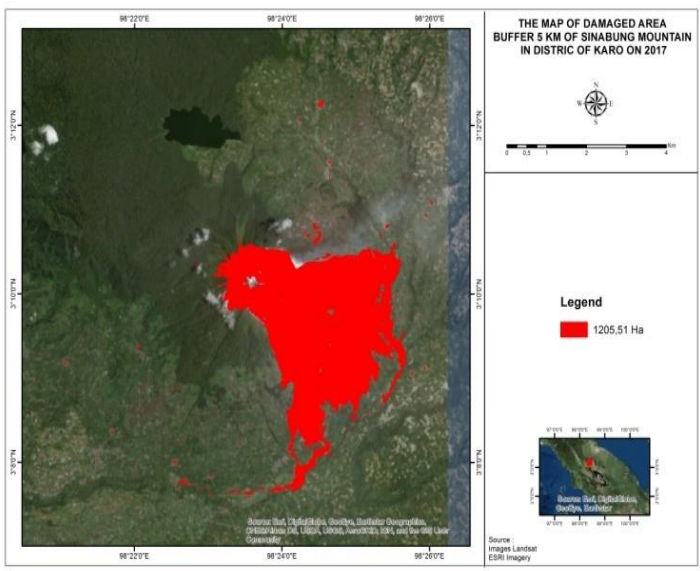

Figure 3.c Land Damage Landsat 8 Oli in 2017

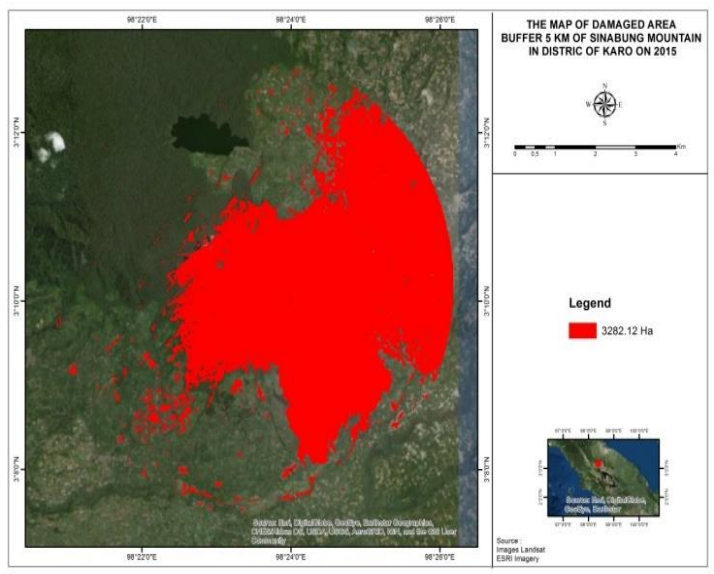


Table 4. Damaged Area Changes at Sinabung Mountain Area

\begin{tabular}{lcc}
\hline No & Year & Width (Ha) \\
\hline 1 & 2015 & 3282.12 \\
2 & 2017 & 1205.51 \\
\hline
\end{tabular}

\subsection{Critical Land}

Critical land obtained from the overlay (overlapping) for forest canopy density maps, slope maps of erosion hazard level maps so that we get a description of critical land in Pakpak Bharat District in Figure 4.

Critical Land Map of Pakpak Bharat Regency for 2014 year, such as:

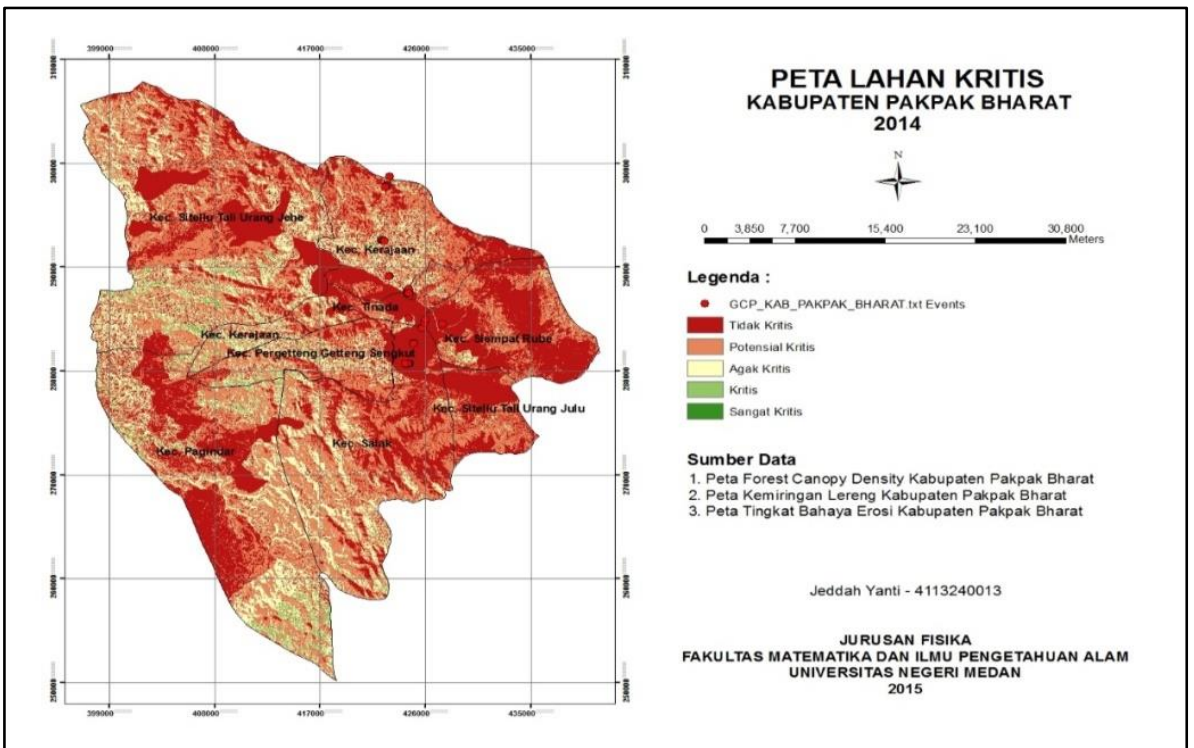

Figure.4. Critical Land Map of Pakpak Bharat Regency in 2014

Table 4. Percentage of Critical Land Level with Critical Land Parameter

\begin{tabular}{|c|c|c|c|c|}
\hline $\begin{array}{l}\text { Kinds of } \\
\text { Critical } \\
\text { Land }\end{array}$ & $\begin{array}{l}\text { Percentage of } \\
\text { Critical Land } \\
\text { Level }(\%)\end{array}$ & $\begin{array}{l}\text { Percentage of } \\
\text { Forest Canopy } \\
\text { Density }(\text { FCD })(\%)\end{array}$ & $\begin{array}{l}\text { Percentage of } \\
\text { Slope }(\%)\end{array}$ & $\begin{array}{c}\text { Percentage of } \\
\text { Erosion } \\
\text { Hazard Level } \\
\qquad(\%)\end{array}$ \\
\hline $\begin{array}{r}\text { No } \\
\text { critical }\end{array}$ & 38.38 & 13.25 & 12.71 & 23.66 \\
\hline $\begin{array}{l}\text { Potential } \\
\text { Critical }\end{array}$ & 42.38 & 35.77 & 19.94 & 20.69 \\
\hline $\begin{array}{l}\text { Rather } \\
\text { critical }\end{array}$ & 16.73 & 23.07 & 25.55 & 34.00 \\
\hline Critical & 2.45 & 23.11 & 26.48 & 16.27 \\
\hline $\begin{array}{l}\text { Very } \\
\text { Critical }\end{array}$ & 0.05 & 4.79 & 15.31 & 5.37 \\
\hline Total & 100 & 100 & 100 & 100 \\
\hline
\end{tabular}


The results of the percentage of critical level of land with critical land parameters, forest canopy density, slope and erosion hazard level can be classified as Table 4.

\subsection{Discussion}

From the results of table 3.1, it states that the high correlation between the intensity observed with spectroscopic MSR cropsan and satellite generated, then from the results of Figure 2 the relationship of temperature measurements in the field and satellite states the same. This shows that both of these studies can prove that remote sensing technology can be accepted scientifically. From result 3 states that NDVI has decreased while result 4 states that there is an increase in temperature, this gives results that there has been a significant environmental change, this is also strengthened by the occurrence of environmental damage to yield 5 in the mountain area Sinabung with $5 \mathrm{~km}$ buffering. From the results 6, it is clear that there has been critical land in Pakpak Barat.

\section{Conclusions}

From the discussion above, it can be concluded that: Remote sensing technology can be accepted scientifically, Remote sensing technology can be used to see environmental changes, land damage, land consistency, and others.

\section{References}

[1]Lillesand, T.M., dan F.W. Kiefer, (1979), Penginderaan Jauh dan Interpretasi Citra, Yogyakarta, Gadjah Mada University Press.

[2]Kumar, D. (2015) Remote Sensing based Vegetation Indices Analysis to Improve Water Resources Management in Urban Environment. Aquatic Procedia, 4, pp. 1374 - 1380.

[3]Srivanit, M. (2012) Assessing the Impact of Urbanization on Urban Thermal Environment: A Case Study of Bangkok Metropolitan. nternational Journal of Applied Science and Technology, 2(7), pp.243-356.

[4]Ahmad, F. (2013) Land Degradation Pattern Using Geo-Information Technology for Kot Addu, Punjab Province, Pakistan. Global Journal Of Human Social Science Geography, GeoSciences \&Environmental, 13(1), pp.1-16.

[5]Higginbottom, T.P., E. Symeonakis. (2014) Assessing Land Degradation and Desertification UsingVegetation Index Data: Current Frameworksand Future Directions. Remote Sens., 6, pp.9552-9575. doi:10.3390/rs6109552.

[6]Gao, J., Y. Liu. (2010) Determination of land degradation causes in Tongyu County, Northeast China via land cover change detection. International Journal of Applied Earth Observation and Geoinformation, 12, pp.9-16.

[7]Li, Z. X. Deng, F. Yin \& C. Yang. (2014) Analysis of Climate and Land Use Changes Impacts on Land Degradation in the North China Plain. Advances in Meteorology, pp.1-11.

[8]Tampubolon, Togi, Khiruddin Bin Abdullah, and Hwee San, Lim, (2013) Application of Spectrometer Cropsan MSR 16R and Landsat Imagery of Identification the Spectral Charateristic of Land Cover, PIPS-2013 AIP Conf. Proc. 1554, 158-161.

[9]Tampubolon, Togi, Juliani, Rita, Harefa Alvin, Evan (2017), Enviromental Change Analysis in Nias Island Using Remote Sensing Technique, International Journal of Computer Science Technology Vol. 8 Issue 2, 134 - 139 